\title{
Between Rudimentary and Artistic: Decorated Starčevo-Criș Pots
}

Anamaria Tudorie*

\begin{abstract}
The article presents new information regarding the percentual distribution of Starčevo-Criş decorated pottery, using the information on the Early Neolithic discoveries from the sites of Miercurea Sibiului-Petriș (Sibiu County), Turdaș-Luncă (Hunedoara County), Săliștea (Alba County), Cristian I (Sibiu County) and Cristian III (Sibiu County). Excepting Miercurea Sibiului-Petriş and Cristian I sites for which, besides the information about the category, color, temper, surface treatment, firing and morphology of this pottery were published in different volumes or articles, also some data regarding the different percentages on types of ornaments were published. This time, the author discusses globally the total amount of decorated pottery, taking into consideration also the relative chronological framings for each of the sites
\end{abstract}

Keywords: Early Neolithic, Starčevo-Criș, pottery, ornamentation, Transylvania

Before referring ourselves to arts and artistic manifestation when describing very old pottery, we should establish first what does arts stand for. Nowadays, the word is being used to describe numerous things, starting from the spectacular Paleolithic cave paintings, to a banana taped on a wall in an art gallery ${ }^{1}$. According to Britannica Encyclopedia, the arts, also called fine arts [are] modes of expression that use skill or imagination in the creation of aesthetic objects, environments, or experiences that can be shared with others ${ }^{2}$.

In the Paleolithic period the forms of decorative art were represented on different objects decorated by incisions or painting, but starting with the Neolithic, this form of art is being represented also on pottery.

The first ceramic pots were not produced to be strong enough to cook in them and the explanation is to be found in the fact that the firing temperature was too low. It is very possible that the first pots to have been fired only by covering them with straws or dry vegetation. There is a study made on Early Neolithic pottery from Hungary ${ }^{3}$, which indicated the fact that it was fired under the temperature of

\footnotetext{
* Lucian Blaga University of Sibiu, Romania, anamaria.tudorie@ulbsibiu.ro

1 https://news.artnet.com/market/maurizio-cattelan-banana-art-basel-miami-beach-1722516

${ }^{2}$ https://www.britannica.com/topic/the-arts

${ }^{3}$ Elisabetta Starnini, György Szakmány, "Studio archeometrico comparativo di manufatti non vascolari in argilla cotta e di contenitori ceramici del neolitico antico ungherese". In Atti della $9^{a}$ Giornata di Archeometria della Ceramica (Pordenone 18-19 aprilie 2005), ed. Bruno Fabbri, Sabrina Gualtieri, Anna Nicoletta Rigoni, (Pordeone: Lithostampa, 2007), 59.
} 
$750-800{ }^{\circ} \mathrm{C}$, so these pots couldn't have been used intensively or to keep liquid products inside them.

The first ceramic pots from the Near East were assumed to be small sized, few, poorly ornamented and fired at low oxidating temperatures ${ }^{4}$, but in an article about the site of Tell Sabi Abyad in Syria, with a stratified sequence passing from the aceramic (pre-pottery) to pottery-using Neolithic around 7000 BC, we find out that the technological evolution in what concerns the fabrication of pottery wasn't a linear one, from simple models to more complex ones. Also, the authors of this study suggest that pottery made little difference to the Neolithic communities. In what concerns the appearance, some of the pots had a glossy aspect due to an intensive smoothing and burnishing. More, the first pots didn't have any vegetables used as temper and the firing was oxidating only for $1 / 3$ and the majority had a darker grey to dark grey color. It seems that the pots were fired by open bonfires, no kilns being identified. Decoration was represented by two categories: applying red slip and by painting ${ }^{5}$. So, the first pottery produced in it did not seem to be so rudimentary as the specialists initially believed.

It is possible that the first pots, represented by carefully made objects and with a quite artistic aspect, to have been used and appreciated as prestige goods and afterwards, to develop in wide-spread object and the technology of production to have a more practical finality ${ }^{6}$.

It is also assumed that the pottery appeared as a need for more containers, at the end of the process of neolithization and without having the porpoise to be used for cooking inside them ${ }^{7}$. More, the first Neolithic communities knew how to work with the clay (it was used before in architecture, for example) and they could have used it form making pottery if they needed to, so in the aspect of the emerge of pots the functionality is an aspect to regard as more important, than the technology itself ${ }^{8}$.

Other containers were used before and still after the production and use of pottery, some of them possibly made of animal skins, or basketry and wood. If for the first two example mentioned it is improbable to find any archaeological remains, for the recipients made of wood, fortunately, we have a few examples of discoveries belonging to Early Neolithic period from Romania.

During two campaigns, between 1980-1981, in the archaeological site from Cârcea, Izlaz point (Olt County), the remains of two wood pots (the fragmented

\footnotetext{
${ }^{4}$ Douglass W. Bailey, Balkan Prehistory Exclusion, incorporation and identity, (London-New York: Routledge, 2000), 6.

${ }^{5}$ Oliver P. Nieuwenhuyse, Peter M.M.G. Akkermans, Johannes van der Plicht," Not so coarse, nor always plain - the earliest pottery of Syria”. In Antiquity, 84, 2010, 76-79.

${ }^{6}$ Nieuwenhuyse," Not so coarse", 83.

${ }^{7}$ Takahiro Odaka," The Emerge of Pottery in the Northern Levant: A Recent view of Tell el-Kerkh". In, The Emergence of Pottery in West Asia, Akira Tsuneki, Olivier Nieuwenhuyse, Stuart Campbell (eds.), (Oxford \& Philadelphia, Oxbow Books, 2017), 68

${ }^{8}$ Mehmet Özdoğan," Earliest Use of Pottery in Anatolia". In Early Farmers, Late Foragers, and Ceramic Traditions: On the Beginning of Pottery in the Near East and Europe, Dragos Gheorghiuv (ed.), (Newcastle upon Tyne, Cambridge Scholars Publishing, 2009), 22-23.
} 
bottoms), the remains of a bracelet and an entire pot were found ${ }^{9}$. A more recent discovery of this type was made at Cristian III site (Sibiu County) during the preventive research between 2011 and 2012: two fragments from a wooden $\operatorname{pot}^{10}$.

The decoration is an intervention on the pot, with an esthetic finality, which should not influence the basic shape of the object. The types of ornament that are being represented on Starčevo-Criș pottery are painting and plastic ornaments. In the last category I have included applications, pinches, impresso type ornaments (made with finger, finger and nail, nail, an object, like a stick or a shell), barbotine, incisions, and excisions ${ }^{11}$. Although the first Neolithic pots had a very artistic aspect due to applying a red-colored slip - a thick layer of high quality clay in order to emphases the color and to improve the pot's texture ${ }^{12}$, and a very good polishing, I have considered these techniques as a part of the technological process in the phase of surface treatment and not as an ornament ${ }^{13}$.

For this paper I am using the information on Starčevo-Criș pottery from the following sites: Miercurea Sibiului-Petriș (Sibiu County), Turdaș-Luncă (Hunedoara County), Săliștea (Alba County), Cristian I (Sibiu County) and Cristian III (Sibiu County). Data regarding the category, color, temper, surface treatment, firing and morphology and seriations were published in two different volumes ${ }^{14}$, without discussing the statistical data on the ornamentation. There are two exception to this situation. The first case is the one of Miercurea Sibiului-Petriș site, statistical data regarding the ornamentation of pottery were published in $2008^{15}$. New data for $\mathrm{B}_{9}$ feature was added ${ }^{16}$ but this situation doesn't change consistently the first analysis made by the authors. The second case is the one of Cristian I site, where some statistical analysis focused on different type of ornaments were published ${ }^{17}$.

Also, as a working method, for Miercurea Sibiului-Petriş site I shall not discuss each feature, but only the data collected from the three Early Neolithic levels

\footnotetext{
${ }^{9}$ Marin Nica," Obiecte de lemn descoperite în așezarea neolitică timpurie de la Grădinile (jud. Olt)". In Arhivele Olteniei, 2, 1983, 39-48.

${ }^{10}$ Sabin Adrian Luca, Adrian Georgescu, Anamaria Tudorie, Florentina Marțiș. CRISTIAN III, realități cronologice și culturale preistorice dovedite prin cercetările preventive, (Suceava: Karl A. Romstorfer, 2017), 203.

${ }^{11}$ Anamaria Tudorie, Aspecte tehnologice ale ceramicii Starčevo-Criş din Transilvania, (Sibiu: Muzeul Național Brukenthal, 2013), 49-50.

${ }^{12}$ Anna O. Shepard, Ceramics for the arcaheologist, (Washington, 1985), 67.

${ }^{13}$ Anamaria Tudorie, Aspecte tehnologice, 48-49.

${ }^{14}$ Anamaria Tudorie, Aspecte tehnologice; Sabin Adrian Luca, Adrian Georgescu, Anamaria Tudorie, Florentina Marțiș. CRISTIAN III.

${ }^{15}$ Sabin Adrian Luca, Dragoș Diaconescu, Cosmin Suciu," Cercetările arheologice de la Miercurea Sibiului - Petriş (judeţul Sibiu, România). Nivelul Starčevo-Criş în campaniile de cercetare din anii 1997-2005”. In Brukenthal. Acta Musei 1.III (2008) Sibiu, p. 7-46.

${ }^{16}$ Anamaria Tudorie, Aspecte tehnologice, 90.

${ }^{17}$ Sabin Adrian Luca, Viața Trăită sub zei. Situl Starčevo-Criș de la Cristian I, județul Sibiu, România / Living under the Gods. The Starčevo-Criș I site from Cristian I, Sibiu County, Romania, (Suceava: Academia Română, Karl A. Romstorfer, 2015),144-145, 162-170.
} 
established for this site: $\mathrm{Ia}, \mathrm{Ib}, \mathrm{Ic}^{18}$. The same approach was considered for the site of Cristian III: to consider globally the entire lot of ceramics belonging to StarčevoCriș culture, as all the features were chronological framed in the same phase of the culture (IIIB) ${ }^{19}$.

As it can be noticed on the graphics presented above (Fig. 1, Fig. 2 and Fig. 3), the percentages on the decorated pottery for levels Ia and Ib are almost similar: $7 \%$ for Ia and $8 \%$ for Ib. There is quite an increase in level Ic (only one feature in this case: $\mathrm{B}_{9}$ ), with $17 \%$. I have also made another interrogation in the data base (not represented graphically here) and from the total amount of the pottery that was ornamented, 93\% had barbotine as the technique used.

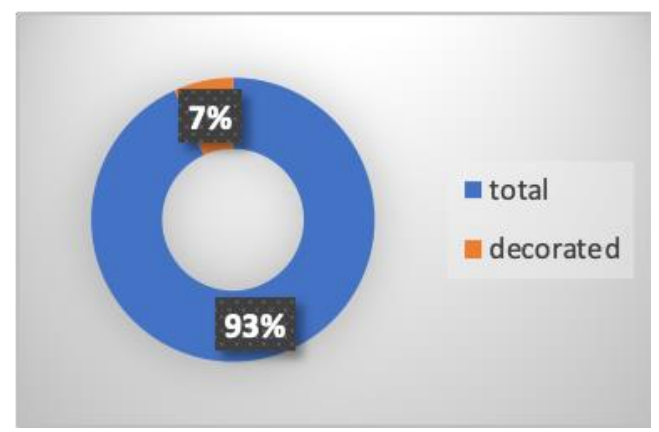

Fig. 1: Miercurea Sibiului-Petriş (Sibiu County), level Ia. The percentual analysis of the decorated pottery.

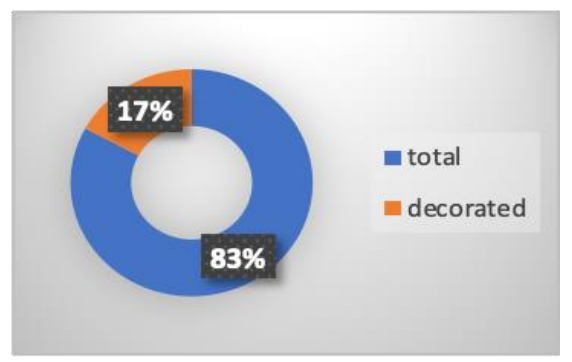

Fig. 3. Miercurea Sibiului-Petriș (Sibiu County), level Ic. The percentual analysis of the decorated pottery.

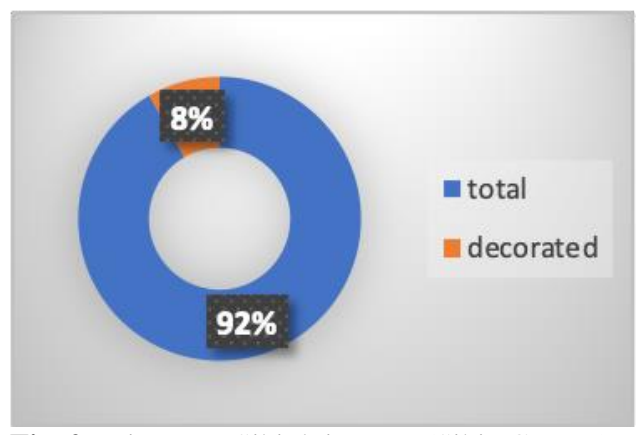

Fig. 2: Miercurea Sibiului-Petriș (Sibiu County), level Ib. The percentual analysis of the decorated pottery.

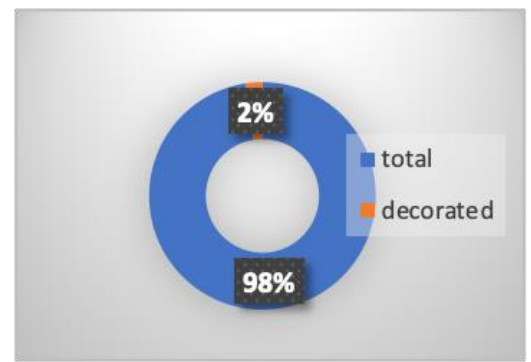

Fig. 4. Turdaș-Luncă (Hunedoara County). The percentual analysis of the decorated pottery.

${ }^{18}$ Sabin Adrian Luca, Dragoş Diaconescu, Cosmin Suciu," Cercetările arheologice de la Miercurea Sibiului - Petriş, 7 .

${ }^{19}$ Sabin Adrian Luca, Adrian Georgescu, Anamaria Tudorie, Florentina Marțiş. CRISTIAN III, 233235. 
The site of Turdaș-Lunca, feature $\mathrm{C} 164^{20}$, has a small percentage of the decorated pottery, only $2 \%$. But, from the decorated pots there are two fragments ${ }^{21}$ that can be regarded as examples of fine arts, being decorated by impressed plastic applications that for the motive of a flower. In the case of the materials discovered at Săliștea, formerly named Cioara ${ }^{22}, 6 \%$ of the pottery presented decoration, but this information must be correlated with the data regarding the fabrication techniques ${ }^{23}$, namely the category: only 2 fragments were framed in the fine category.

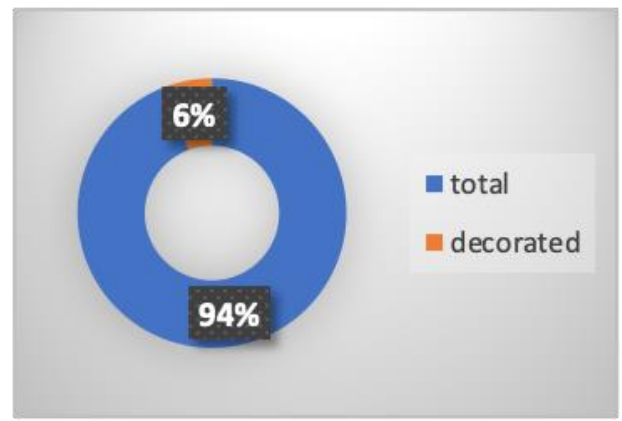

Fig. 5. Săliștea (Alba County). The percentual analysis of the decorated pottery.

\footnotetext{
${ }^{20}$ Sabin Adrian Luca, Anamaria Tudorie, Marius-Mihai Ciută," Data concerning $\mathrm{C}_{164}$ feature from Turdaș-Luncă (Hunedoara County)". In Acta Terrae Septemcastrensis, no. XI (2012), 7-20 ; Sabin Adrian Luca, Un oraș preistoric din Europa. TURDAȘ-Luncă, Sectorul A, I.1, (Sibiu: Editura Universității Lucian Blaga din Sibiu, 2019), 28-36.

${ }^{21}$ Sabin Adrian Luca, Anamaria Tudorie, Marius-Mihai Ciută," Data concerning $\mathrm{C}_{164}$ feature, Pl. III, 7-8; Sabin Adrian Luca, Un oraş preistoric din Europa, Photo 16.

${ }^{22}$ Sabin Adrian Luca, Anamaria Tudorie," Another Early Neolithic site discovered in Alba County. The Starčevo-Criș Settlement from Săliștea (Cioara, Romania)". In Acta Terrae Septemcastresis, no. XI, 2012, 21-32.

${ }^{23}$ Sabin Adrian Luca, Anamaria Tudorie," Another Early Neolithic site discovered in Alba County, 2225.
} 


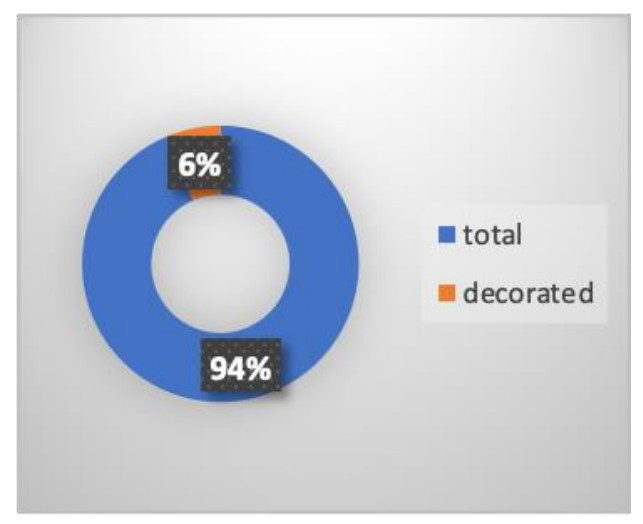

Fig. 6. Cristian I (Sibiu County), feature L1. The percentual analysis of the decorated pottery.

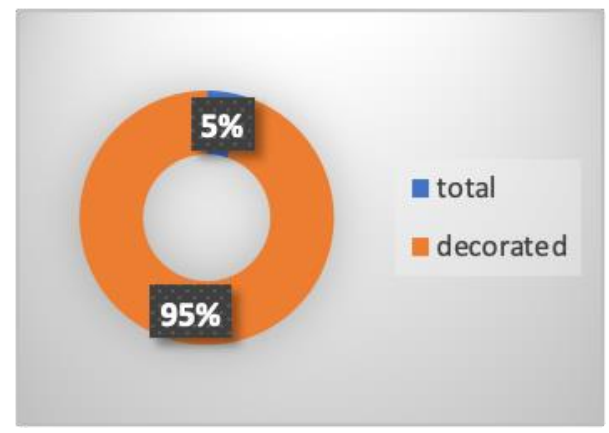

Fig. 8. Cristian I (Sibiu County), feature L3. The percentual analysis of the decorated pottery.

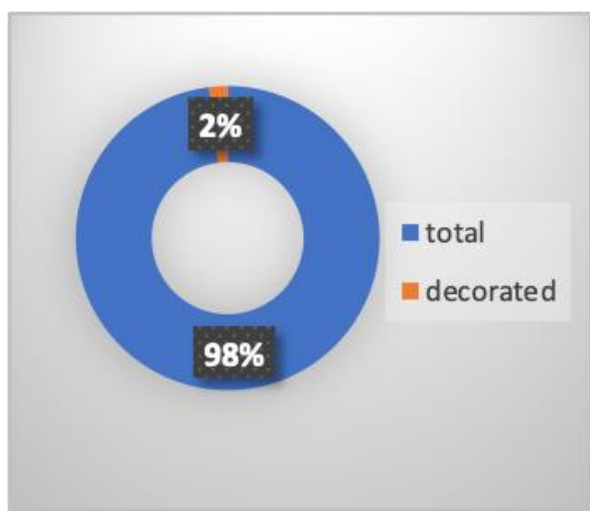

Fig. 7. Cristian I (Sibiu County), feature L2. The percentual analysis of the decorated pottery.

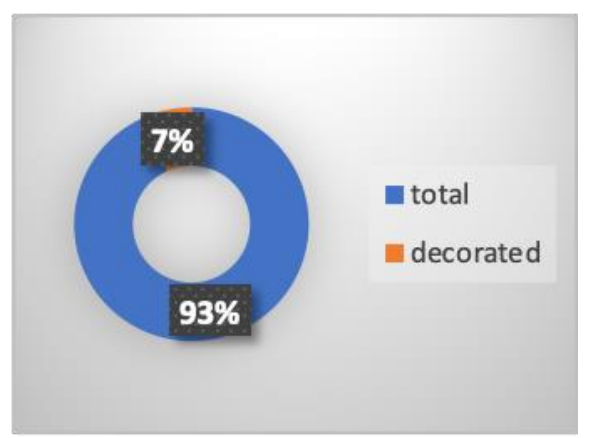

Fig. 9. Cristian III (Sibiu County). The percentual analysis of the decorated pottery.

For the site of Cristian, $\mathrm{I}^{24}$, the statistical data regarding the presence of ornamented pots indicates that for L1 (represented on Fig. 6), 6\% of the total amount of ceramics presented ornaments. In the case of L2 (Fig. 7) there were identified only $2 \%$ of decorated pot and the explanation of this situation is to be found in the special destination of this area: a sanctuary with ritual pits $^{25}$. Inside these pits numerous pots, were discovered and for many of them the restauration was possible ${ }^{26}$. Also, in this zone, a special and unique pot was discovered: the twomouth pot and from feature $\mathrm{C}_{58}{ }^{27}$, which I consider that represents, itself, an example of Early Neolithic fine arts. For L3, there is an amount of 5\% of decorated pottery.

\footnotetext{
${ }^{24}$ Sabin Adrian Luca, Viața Trăită sub zei.

${ }^{25}$ Sabin Adrian Luca, Viața Trăită sub zei, 21-99.

${ }^{26}$ For more information regarding the number of pits, shape and number of pots discovered inside and the graphic representation of this area see: Sabin Adrian Luca, Viața Trăită sub zei, Plan 4, Plan 5 and Tabel sintetic 1, 25-28.

${ }^{27}$ Sabin Adrian Luca, Viața Trăită sub zei, 66-69.
} 
The last analyzed site was the one from Cristian $\mathrm{III}^{28}$ and as is being indicated on the graphic at Fig. 9, from the entire lot of analyzed pottery, 7\% was decorated. Connecting this information with the data regarding the general aspect ${ }^{29}$ we can see that only $4 \%$ of the ceramics were considered to belong to the fine category, while semi-fine represent $72 \%$ and rough $24 \%$.

Today, pottery is one of the oldest and widespread forms of decorative arts and some of the first pots made by the early Neolithic communities from Transylvania make no exception. If we can say that some the first pots produced by the Early Neolithic people from the territory of Romania were indeed artistic, this assertion should not be extended when referring ourselves to all decorated pottery.

First, we should regard the data we have on the technology of Starčevo-Criș pottery production ${ }^{30}$, not being enough to establish how many of these pots were decorated and how many were not. As the graphics presented above indicated, a quite small percentage of the pottery was decorated, the numbers varying between $2 \%$, the lowest, and $17 \%$ the highest. But it is very important to emphasize the fact that not all the sherds that presented a decoration can be regarded as artistic object, as special ones. This aspect should be in direct dependency with other elements from the process of production: the selection of clay, temper, the surface treatment, and firing.

And the other aspect that we should take into consideration is the fact that for the first phase of the cultural complex, as Gh. Lazarovici defined it ${ }^{31}$, IA, named also Monocrom or Frühkeramik ${ }^{32}$, the pots had a monochrome aspect, with a high quality of production (due to the materials used for tempering, as is the fine sand) and a great attention in the surface treatment, by applying a well-polished reddishbrownish slip, which can easily include the ones in a very good conservation conditions in the category of fine arts.

\footnotetext{
${ }^{28}$ Sabin Adrian Luca, Adrian Georgescu, Anamaria Tudorie, Florentina Marțiș. CRISTIAN III.

${ }^{29}$ Sabin Adrian Luca, Adrian Georgescu, Anamaria Tudorie, Florentina Marțiș. CRISTIAN III, 210.

${ }^{30}$ Anamaria Tudorie, Aspecte tehnologice; Sabin Adrian Luca, Adrian Georgescu, Anamaria Tudorie, Florentina Marțiș. CRISTIAN III, 210-211

${ }^{31}$ Gheorghe Lazarovici, Neoliticul Banatului, (Cluj-Napoca: Bibliotheca Musei Napocensis, 1979), 19.

${ }^{32}$ Gheorghe Lazarovici, Neoliticul Banatului, 16.
} 


\section{LIST OF ILLUSTRATIONS}

Fig. 1. Miercurea Sibiului-Petriş (Sibiu County), level Ia. The percentual analysis of the decorated pottery.

Fig. 2. Miercurea Sibiului-Petriș (Sibiu County), level Ib. The percentual analysis of the decorated pottery.

Fig. 3. Miercurea Sibiului-Petriș (Sibiu County), level Ic. The percentual analysis of the decorated pottery.

Fig. 4. Turdaș-Luncă (Hunedoara County). The percentual analysis of the decorated pottery.

Fig. 5. Săliștea (Alba County). The percentual analysis of the decorated pottery. Fig. 6. Cristian I (Sibiu County), feature L1. The percentual analysis of the decorated pottery.

Fig. 7. Cristian I (Sibiu County), feature L2. The percentual analysis of the decorated pottery.

Fig. 8. Cristian I (Sibiu County), feature L3. The percentual analysis of the decorated pottery.

Fig. 9. Cristian III (Sibiu County). The percentual analysis of the decorated pottery. 